\title{
HEREZJA ARTYSTYCZNA - HEREZJA SOCJOLOGICZNA, CZYLI „MANET TO JA”
}

\section{PIERRE BOURDIEU}

\section{MANET. UNE RÉVOLUTION SYMBOLIQUE. COURS AU COLLĖGE DE FRANCE [1998-2000] SUIVIS D'UN MANUSCRIT INACHAVÉ DE PIERRE ET MARIE-CLAIRE BOURDIEU}

Tomasz Warczok

Uniwersytet Pedagogiczny w Krakowie

Książka Manet. Une révolution symbolique jest w przeważającej mierze transkrypcją osiemnastu wykładów wygłoszonych przez Pierre’a Bourdieu w Collège de France w latach 1998-2000. W tomie znalazł się także obszerny „nieukończony manuskrypt” przygotowany przez Bourdieu i jego żonę, Marie-Claire Bourdieu, zatytułowany Manet l'hérésiarque. Genèse des chaps artistique et critique (Manet herezjarcha. Geneza pola artystycznego i pola krytyki).

Książka poświęcona jest rewolucji w malarstwie współczesnym, wywołanej przez Édouarda Maneta (1832-1883), artystę, który uważany jest nie tylko za protoplastę impresjonizmu, lecz także za tego, który zapoczątkował „sztukę nowoczesną” per se. Bourdieu próbuje wyjaśnić wielowymiarowy mechanizm „rewolucji symbolicznej”, czyli takiej transformacji, która zmienia zarówno struktury społeczne, jak i struktury poznawcze, „sposoby widzenia" rzeczywistości - w tym wypadku rzeczywistości sztuki. Proponowana przez autora Dystynkcji teoria zmiany społecznej ma jednak walor uniwersalny, może być aplikowana do analizy przekształceń w różnych uniwersach - politycznych, ekonomicznych czy religijnych. Te ostatnie sa 
dla Bourdieu szczególnie ważne, co znajduje wyraz w konsekwentnie stosowanym słowniku, znanym $z$ innych jego prac (orto- $i$ heterodoksja, ekskomunika, herezjarcha, prorok itd.).

Wykłady wygłoszone zostały zgodnie z tradycja Collège de France dla szerokiej i zróżnicowanej publiczności, dlatego język głównego wywodu jest dość zrozumiały. Bourdieu wraca stale do kilku zasadniczych wątków, przygląda się im z wielu stron, uzupełnia je dygresjami metodologicznymi. Wspomniany manuskrypt, będący podstawą wykładów, jest bardziej zwarty (chociaż opatrzony szkicowymi uwagami) i można go czytać jako uzupełnienie transkrypcji.

Nie jest bez znaczenia, że manuskrypt powstawał na przełomie lat 80 . i 90., a więc dokładnie wtedy, kiedy Bourdieu pracował nad Regułami sætuki (2001), pracą poświęconą wyłanianiu się w dziewiętnastowiecznej Francji autonomicznego uniwersum literackiego. Obie pozycje odnoszą się do podobnej problematyki, wyjaśniaja generalny mechanizm uniezależniania się kultury od „władzy doczesnej” - bądź to prymatu pieniądza (rynku), bądź polityki (państwa). Jeżeli w polu artystycznym inkarnacją rewolucji jest Édouard Manet, to w polu literackim jego odpowiednikiem pozostaje Gustave Flaubert. Co ciekawe, obie postaci łączy nie tylko podobne podejście do materii sztuki (formalizm, przywiązanie do zasady sztuki dla sztuki, niezgoda na podporządkowanie twórczości jakiejkolwiek zewnętrznej funkcji, np. politycznej czy ekonomicznej), lecz także zbliżone cechy społeczne (obaj pochodzili z wyższych klas społecznych). Już to zestawienie unaocznia fałszywość popularnego mniemania, że to, co przynależy sztuce, jest wyłącznym dziełem genialnych, wyjątkowo utalentowanych jednostek. Bourdieu konsekwentnie demistyfikuje tak rozumiana , ideologię charyzmatyczną", wyjaśniając, że wszelka ludzka działalność, także intelektualna bądź artystyczna, powstaje na styku działania biologicznej, ale uspołecznionej jednostki (wyposażonej w szereg nabytych i słabo uświadomionych dyspozycji) oraz szerszego i węższego kontekstu społecznego, w którym owo działanie się odbywa.

Najpierw więc Bourdieu kreśli obraz szerokiego, dominującego w pierwszej połowie XIX wieku kontekstu instytucjonalnego sztuki. Nie istniała jeszcze wówczas wolna przestrzeń, w której twórcy mogli konkurować. Działalność artystyczna zmonopolizowana była przez sieć powiązanych ze sobą instytucji kontrolowanych przez państwo, takich jak salony, Instytut Francuski, Akademia Sztuk Pięknych, które nie tylko w prawomocny sposób określały, czym jest sztuka, lecz także miały monopol na reprodukowanie samego korpusu twórców. Centralnie organizowane kon- 
kursy definiowały bezdyskusyjne kryteria artyzmu, zajęcie dobrego miejsca w nich wyznaczało zaś drogę standardowej kariery malarzy. Kariera taka miała charakter „biurokratyczny”, nie była, jak się to stanie później, celebrowanym życiorysem artysty, lecz nudną ścieżką pokonywania kolejnych obowiązkowych szczebli. Trudno nawet nazwać ówczesnych twórców artystami, byli raczej „mistrzami” zajmującymi się egzekwowaniem i realizowaniem z góry narzuconych szczegółowych standardów (ćwiczono się w imitacji, dobre kopie były niemalże tak samo cenne jak oryginały). Podobne nastawienie panowało w atelier, do których uczęszczali młodzi adepci malarstwa. Były to szkoły normalizacji i posłuszeństwa wobec dominujących, bezdyskusyjnych norm estetycznych. Nie bez znaczenia był fakt, że w przeważającej mierze uczniowie ci wywodzili się z drobnomieszczaństwa - podobnie więc jak oblaci w Kościele katolickim, zawdzięczając wszystko, co uzyskali, instytucji, nie byli skłonni w jakikolwiek sposób buntować się przeciw niej. Dominująca estetyka, tryb pracy, a nawet sposób ubierania się odpowiadały przy tym etyce. Ideałem była codzienna rutyna, praca w określonych, ściśle przestrzeganych godzinach, czystość i przewidywalność. Podejście to stanowiło więc całkowite zaprzeczenie postaw bohemy artystycznej. Twórcy socjalizowani w takich warunkach pozostawali prostymi wykonawcami, wręcz artystycznymi „funkcjonariuszami państwa”, które, jako niekwestionowana „maszyna klasyfikująca”, swego rodzaju „centralny bank symboliczny wartości artystycznych” (Bourdieu 2013: 187), narzucała kategorie i hierarchie - nie tylko dzieł, lecz także samych twórców.

Nie może dziwić, że sztuka, która w takich warunkach powstawała, miała charakter przewidywalny i zestandaryzowany. Pogardliwie zwana „pompierską” („,strażacką" - od motywu hełmu strażackiego, który często pojawiał się wówczas na płótnach), odznaczała się czytelnością, narracyjnością i obecnością łatwo zrozumiałych znaczeń. Ceniona przez mieszczaństwo, dostosowana była do jego „literackiego” wykształcenia (nie trzeba było rozróżniać, jak w przypadku sztuki współczesnej, stylów i manier malarskich). Stanowiąc zaprzeczenie osiemnastowiecznej estetyki arystokratycznej, w swej bezpiecznej ortodoksyjności podtrzymywała ład symboliczny, zwłaszcza w czasach zawirowań społecznych II Republiki i II Cesarstwa.

Rewolucja, którą uosabiał Édouard Manet, całkowicie zerwała z tym porządkiem symbolicznym. Dobrze znane, tysiące razy interpretowane Śniadanie na trawie, wystawione po raz pierwszy na Salonie Odrzuconych w 1863 roku, wyraża, jak pokazuje Bourdieu, wszystko, co najbardziej subwersywne 
w tej rewolucji. Przede wszystkim obraz ten wprowadził zamęt w narzuconą i traktowaną jako oczywistość siatkę klasyfikacyjna sztuki akademickiej. Zakłócił i odwrócił istniejące, uważane za święte, hierarchie. Przedstawia bowiem sytuację banalna (spotkanie kilku osób namalowanych jak martwa natura) na płótnie o znacznych rozmiarach (taki rozmiar zarezerwowany był dla tematów najbardziej wartościowych, religijnych czy historycznych). Niszczy więc uświęconą hierarchię wysokie/niskie. Wedle ówczesnych standardów jest dziełem nieskończonym, zaledwie szkicem (zarzucano mu błędy techniczne, błędy w perspektywie itd.), a więc zamiast być barbarzyńsko wystawiony na widok publiczny, powinien pozostać nadal w sferze prywatnej (atelier). Ma to jasne konotacje moralne, gdyż eksponuje to, co „łatwe”, przeciwstawiając się „skończoności”, a więc trudowi, samej etyce pracy. W równie barbarzyński sposób dzieło nawiązuje, niemalże parodystycznie, do twórców klasycznych (Tycjana i Rafaela Santiego), a zatem ipso facto burzy hierarchię klasyczne/współczesne. Najbardziej skandalizujące było rzecz jasna brutalnie realistyczne ukazanie postaci nagiej kobiety, w odważny sposób patrzącej na odbiorcę. Kobieta ta, w domyśle prostytutka z klas niższych, siedzi w towarzystwie dwóch wyglądających na studentów mężczyzn. Jest to więc transgresja nie tylko estetyczna, lecz także społeczna. Stanowi symboliczne zagrożenie dla biologicznej reprodukcji różnic społecznych, a więc podważa sam ład moralny. Przy tym Śniadanie na trawie, podobnie jak liczne inne prace Maneta, o niczym nie opowiada; jest „płaskie”, i to w podwójnym sensie. Nie ma w nim perspektywicznej głębi i gry światłocieni charakterystycznych dla dzieł pompierskich, nie niesie też żadnych czytelnych znaczeń. Płótno to jest w ścisłym sensie malarskie. Manet, akcentując dwuwymiarowość, odrzuca skojarzenia z rzeźbą; rezygnując z narracji, oddziela malarstwo od literatury. W szerszym planie społecznym jego twórczość jest więc wyrazem autonomizowania się całego mikrokosmosu artystycznego, relatywnego uniezależnienia się nie tylko od sił politycznych czy ekonomicznych (sztuka nie może być podporządkowana żadnej władzy doczesnej, żadnej funkcji), lecz także od innych uniwersów kulturowych, takich jak mikrokosmos literacki. Nie jest przypadkiem, że tą samą ścieżka formalnych poszukiwań poszedł w polu literackim Flaubert (odrzucenie prostego realizmu, „zimny” styl narratora, często trzecioosobowego itd.). Odejście w stronę „,czystej formy”, właściwej dla danej sztuki („czysta forma" literacka, malarska, poetycka) jest bowiem uniwersalna zasada związaną z procesem jej autonomizacji (można tu podać przykłady „formalizmu” prawa czy nauki, np. matematyka jako nauka z gruntu formalna tworzy równocześnie wyjątkowo autonomiczne pole społeczne). 
Skandal Maneta unaocznia dobitnie mechanizm społecznego funkcjonowania sztuki oraz wszelkich innych obiektów symbolicznych. Oburzenie, jakie towarzyszyło wystawieniu prac tego autora, wynikało z aktu prawdziwego świętokradztwa, które jak powtarza Bourdieu za Durkheimem, polega zawsze na przekraczaniu granic - między publicznym i prywatnym, wysokim i niskim, męskim i żeńskim, łatwym i trudnym: ,[...] granice sa szczególnie uświęcone, ponieważ jednocześnie przynależą samej rzeczywistości - jak w przypadku progu domu oddzielającego to, co żeńskie, i to, co męskie, to, co wewnątrz, i to, co na zewnątrz - ale także wpisane są w nasze głowy [...]; pozostają one podziałami obiektywnymi, ucieleśnionymi w formie zasad postrzegania i podziału" (Bourdieu 2013: 54). Autor Śniadania na trawie naruszył i odwrócił sakralizowane, całkowicie nieświadomie przyjmowane klasyfikacje i hierarchie, które zawsze zdeponowane są obiektywnie w samych namacalnych obiektach rzeczywistości (w tym wypadku w dziełach sztuki) oraz w umysłach, a nawet ciałach - w ucieleśnionych schematach postrzegania świata. Fakt ten tłumaczy, dlaczego skandal tego rodzaju wywołuje zazwyczaj silną reakcję emocjonalną. Odnosi się bowiem do sfery niedyskursywnej, nieświadomej, wręcz psychosomatycznej. Wbrew długiej, intelektualistycznej tradycji europejskiej, ściśle oddzielającej ciało od duszy (lub umysłu), nie można zapominać, że ciało także „myśli”, a podstawowych hierarchii społecznych jednostki uczą się poprzez cielesne $z$ gruntu działania (rytuały w relacjach między płciami czy między podwładnymi i przełożonymi itd.). Także odbiór sztuki ma charakter w przeważającej mierze nieświadomy, uruchamia najpierw głęboko uwewnętrznione schematy, a nie idee czy przekonania (co tłumaczy, dlaczego dany obiekt artystyczny obrzydza bądź w trudny do wyrażenia sposób zachwyca). Warto jednocześnie pamiętać, że podobne podejście nie oznacza podążania w kierunku naiwnego freudyzmu czy modnej dziś lacanowskiej psychoanalizy społecznej. Francuski socjolog nie mówi o arbitralnie analizowanej indywidualnej nieświadomości, ale o w pełni empirycznie uchwytnej „nieświadomości kulturowej”, zwanej także doxa (por. Bourdieu 2006).

Jak zaznacza Bourdieu, nie chodzi tu tylko o przesunięcie akcentów, ale całościową zmianę widzenia ludzkiego działania, także działania artystycznego. Proponuje więc nowy paradygmat analizy praktyk oraz obiektów artystycznych i intelektualnych, odrzucając bądź znacznie modyfikując utrwalone podejścia w historii sztuki, historii idei, socjologii czy filozofii społecznej. Zgodnie z tym, co pisał już wcześniej (Bourdieu 2006), odnosi się to do całej „filozofii świadomości”, perspektywy postrzegania ludzkiego 
działania kierowanego rzekomo świadomą intencją lub też równie świadomie dostępną motywacją. Takie podejście jest szeroko rozpowszechnione, stanowi podstawę różnych odmian teorii racjonalnego wyboru, teorii gier, fenomenologii, personalizmu chrześcijańskiego itd. Wynika natomiast, mówiąc w skrócie, z nieświadomego projektowania na badane jednostki własnej, refleksyjnej postawy, jaka jest udziałem intelektualistów. Podobna postawa, zwana „scholastycznym skrzywieniem” (Bourdieu 2013: 100), ma swoje źródła w niezaangażowanym, zdystansowanym oglądzie rzeczywistości, dokonywanym przez pryzmat abstrakcyjnych modeli, teorii, koncepcji, diagramów i wykresów, które mimochodem ,wkłada się" w głowy zwykłych uczestników życia społecznego. W badaniach nad sztuką znajduje to wyraz w koncepcji jednostkowego „twórcy”, „kreatora”, mającego w procesie tworzenia żonglować koncepcjami i ideami innych autorów, którzy rzekomo wywarli na niego wpływ. Historycy sztuki, spierając się więc nieustannie, poszukują $\mathrm{w}$ danym obiekcie artystycznym określonych źródeł, tropią ślady wpływu innych, wcześniejszych twórców, stylów i idei. Taka szkolarska, hermeneutyczna analiza jest typowym oglądem profesorskim, przeprowadzanym z punktu widzenia uczonego lectora, który, zapoznając społeczne warunki tworzenia, fałszywie stawia się w pozycji auctora. Postrzega on dzieło artystyczne jako rebus, palimpsest przeznaczony do pogłębionej deszyfryzacji. Jest to ogląd widza, ogląd dzieła już skończonego, opus operatum, podczas gdy należy, powiada Bourdieu, rzecz odwrócić, przyjrzeć się samej praktyce, przeanalizować szczegółowo modus operandi. Zrekonstruować zatem trzeba uwarunkowania strukturalne, które umożliwiają tworzenie. Mówiąc inaczej, niezbędna jest metodyczna analiza kontekstu, a nie poleganie wyłącznie na „tekście” - do czego przyzwyczaiła nas analiza czysto formalna (w niezrozumiały sposób wskrzeszona niedawno w postaci nawoływań do traktowania całości kultury jako „tekstu”). Bourdieu nawiązuje tu do semiologii, przede wszystkim zaś do ikonologii, zapoczątkowanej przez Ervina Panofskiego, widząc w tym nurcie typowy przykład ,intelektualizmu”, szkolarskiego, arbitralnego poszukiwania znaczeń w obiekcie artystycznym, traktowania go jako zbioru przypisów. Zamiast jednak odrzucać ten nurt en bloc, należy, przekonuje francuski badacz, swoiście go zsocjologizować, zaakcentować samą społeczną praktykę tworzenia znaczeń ${ }^{1}$.

\footnotetext{
${ }^{1}$ Warto pamiętać, że sztandarowa dla Bourdieu koncepcja habitusu rozwinięta została m.in. dzięki studiom Panosfkiego nad wspólnymi, społecznymi źródłami architektury gotyckiej i scholastyki, zob. posłowie do francuskiego wydania Architecture gotbique et pensée scolastique, opublikowane w tym tomie „Stanu Rzeczy”, s. 163-187, oraz komentarz do niego, s. 188-193.
} 
Działanie artystyczne nie jest więc indywidualnym aktem świadomości, artysta nie operuje koncepcjami ani ideami, pod których ma być „wpływem", zdeponowanymi w jego pamięci, do której ma wolny i nieskrępowany dostęp. Sztuka, powtarza za Durkheimem Bourdieu, stanowi „czysta praktykę bez teorii" (Bourdieu 2013: 682), w której biorą udział konkretne jednostki, wyposażone w konkretne dyspozycje. Rozwijana w ten sposób „teoria dyspozycjonalizmu” przeciwstawia się więc zarówno „teoriom intencji”, jak i tym ujęciom, które podmiotu prawdziwie działającego nie dostrzegają, sytuując go co najwyżej w roli prostego „nośnika” struktur (rozmaite odmiany strukturalizmu). Akt tworzenia, podobnie jak każde, nawet najbardziej banalne działanie codzienne, trzeba widzieć , ,[...] w terminach spotkania pomiędzy dyspozycjami - rozumianymi jako system zinkorporowanych i nieświadomych sposobów myślenia - oraz przestrzeni będącej polem możliwości” (tamże: 67). Dla Maneta owo pole to ówczesny mikrokosmos artystyczny, z poszczególnymi pozycjami zajmowanymi przez innych twórców, współczesnych i klasycznych, wobec których musiał zająć własna pozycję. Znowu, nie chodzi tu o świadomy, wykalkulowany akt dystynkcji czy też celowe odróżnianie się od innych. Nawiązania, cytowania bądź zaprzeczenia, będące przedmiotem analiz ikonologów, występują w każdej twórczości, maja jednak charakter praktyczny, a nie czysto intelektualny. „Każde pociagnięcie pędzla jest równocześnie wolne i ustrukturyzowane" (tamże: 138) - dokonuje go artysta swoją zsocjalizowaną ręka, kierując się zsocjalizowanym spojrzeniem, zgodnie z wcielonymi dyspozycjami nabytymi w rodzinie, szkole, atelier itd., które spotykaja się z kolei z danym polem, a więc „strukturą możliwości”: siecia pozycji innych artystów i instytucji wyznaczających w praktyczny sposób ścieżkę tego, co możliwe i niemożliwe. Pole jest zatem zbiorem mniej lub bardziej uświadomionych punktów orientacyjnych, a nie zestawem cytowań.

Aby doszło do rewolucji symbolicznych, konieczny jest określony stan pola. Nie dokonuja jej genialne jednostki czy obdarzeni charyzmą liderzy. Charyzma, która według Webera (2002) miała przejawiać się w debanalizacji, zerwaniu, niewiele tłumaczy, gdyż sama jest charakterystyką społecznie skonstruowaną, uzależnioną od zaistnienia określonych warunków strukturalnych. W drugiej połowie XIX wieku we Francji takimi korzystnymi warunkami była nadprodukcja dyplomów szkół średnich i wyższych. Toteż całe pole produkcji kulturowej poszerzyło się o masę marginalnej, ale jednak znaczacej „proletariackiej” (a nawet „subproletariackiej”) inteligencji (w swej kondycji przypominającej nieco dzisiejszy prekariat). To ta właśnie zbiorowość ukonstytuowała słynną bohemę artystyczną, tworząc z jednej 
strony konkurencyjne wobec państwowych ośrodki produkcji kultury (kawiarnie, kontrsalony itd.), z drugiej zaś stając się istotnym audytorium dla heretyckich przedstawień symbolicznych. Strukturalnie odpowiadała więc analogicznym przekształceniom z 1968 roku, które także zrodziły swoich heretyków w polu intelektualnym (np. Foucault, Derrida) oraz, po stronie recepcji kultury, tzw. nową klasę średnią (Bourdieu 1984, 2005).

Jako że pole sztuki jest rynkiem, wymianą obiektów symbolicznych, a więc takich, którym towarzyszy wiara w ich szczególną wartość, konieczni są agenci, którzy ową wiarę wytworzą i podtrzymają. Te quasi-magiczną funkcję, alchemię przekształcenia zwykłego przedmiotu w przedmiot mający wartość artystyczna, zrealizowali pisarze, wchodzący na scenę w momencie, kiedy załamał się państwowy monopol w tym względzie. Doszło zatem do współpracy między dominującym (bo starszym) polem literackim a podporząakowanym mu, wyłaniającym się, polem artystycznym. Dość szybko ukonstytuowało się na tym tle pole krytyki artystycznej, w którym gra odbywała się w sposób homologiczny do pola sztuki. Jeżeli więc to ostatnie rozciągało się w drugiej połowie XIX wieku od ortodoksji bieguna akademickiego do heterodoksji ówczesnej awangardy, to podobnie pole krytyki podzielone było na część bliską, ,władzy doczesnej” (instytucje państwowe, mieszczańska publiczność) oraz część relatywnie autonomiczna. W takim układzie wsparcie bądź odrzucenie przebiegało homologicznie: apologetycznie pisali o Manecie ci, którzy w polu krytyki znaleźli się po stronie „wznoszącej” - konsekrowanej awangardy, krytykowały zaś osoby, które z racji bliskości bankrutujących symbolicznie instytucji państwa (Akademia, salon itd.) na rewolucji straciły; zgodnie z powtarzającą się manierą wszystkich tracących swoją pozycję niegdysiejszych dominujących, odwoływali się oni do dyskursu końca i upadku sztuki albo nawet całej kultury czy cywilizacji (wystarczy per analogiam pomyśleć o międzywojennych Niemczech i Spenglerowskim dyskursie zmierzchu, upadku, końca; zob. także Bourdieu 1988).

Rewolucyjną konfigurację pola sztuki dopełniły subwersywne, indywidualne dyspozycje (habitus) samego Maneta oraz posiadany przezeń kapitał. Co ciekawe, występując przeciwko akademizmowi, tworząc heretycką przestrzeń wyłaniającego się pola artystycznego, Manet nie utożsamiał się z bohemą. Wywodził się bowiem, inaczej niż większość artystów tej grupy, z rodziny mieszczańsko-arystokratycznej - ideowo sytuującej się wszelako po stronie republikanizmu. Jego podzielony w ten sposób habitus (babitus clivé) pozwalał mu więc zachowywać równą odległość zarówno wobec establishmentu, jak i awangardy. Odziedziczony kapitał społeczny dawał 
dostęp do salonów, w których poznawał bankierów, ale też malarzy czy poetów (np. Baudelaire’a). Rodzinny kapitał ekonomiczny uwalniał od konieczności sprzedawania własnych prac (a więc stanowił zabezpieczenie przed wyrokami rynku), z kolei specyficzny kapitał kulturowy (sześć lat terminowania $\mathrm{w}$ atelier znanego i cenionego Thomasa Couture'a, liczne podróże, w których poznawał sztukę europejską) dawał pełną swobodę warsztatowa. Dystans wobec bohemy manifestował się u Maneta, zgodnie z założeniem o ogólnej spójności habitusu, w zróżnicowanych kontekstach. Nosił się elegancko, pracował wytrwale i rutynowo, nie zerwał kontaktów z rodziną (jak Claude Monet i inni impresjoniści), w samej twórczości zaś, podobnie jak Gustave Flaubert w literaturze, odżegnywał się od charakterystycznego dla bohemy „zaangażowania społecznego”, przeciwstawiając się zwłaszcza bezpośredniemu realizmowi estetycznemu, któremu hołdował na przykład jego konkurent Gustave Courbet (nieprzypadkowo pochodzący z rodziny o znacznie niższym statusie). Habitus Maneta „kierował" go więc, tak jak Flauberta, ku pozycjom w przestrzeni sztuki, które należało dopiero wytworzyć, miejscu pomiędzy ortodoksją zależnego od państwa i burżuazji akademizmu oraz „zaangażowaną społecznie” awangardą. Miejscu, które stanie się przestrzenia ,,sztuki czystej”, prawdziwym polem artystycznym. Przykład ten po raz kolejny potwierdza, że rewolucje nigdy nie są dziełem pariasów, samouków czy twórców „naiwnych”. W sprzyjających warunkach społecznych przeprowadzić je moga tylko ci, którzy dysponując odpowiednim zasobem specyficznych dla danego pola kapitałów, moga je przeciwko niemu zwrócić. A zatem ogólna teza Webera (2006), wywiedziona z rozważań nad starożytnym judaizmem, mówiąca o tym, że heretykami są zawsze byli kapłani, pozostaje, jak pokazuje Bourdieu, w mocy.

\section{$* * *$}

Uczciwie powiedzieć trzeba, że tak jak to się miało z wydanym w 2012 roku pierwszym z serii wykładem Bourdieu w Collège de France, poświęconym państwu (Bourdieu 2012), czytelnicy zaznajomieni z jego teoria nie znajdą w Manet. Une révolution symbolique wielu nowych rzeczy. Podstawowe wyjaśnianie mechanizmów działania pola, habitusu, magii kapitału symbolicznego, a także rewolucyjnej zmiany społecznej znaleźć można w licznych wcześniejszych pracach autora. Ogólne tezy dotyczące rewolucji symbolicznej Maneta pojawiły się już z resztą w artykule z 1987 roku zatytułowanym Linstitutionnalisation de l'anomie (Bourdieu 1987). Recenzo- 
wana książka jest ich detalicznym rozwinięciem (treść artykułu znalazła się w pierwszych dwóch rozdziałach książki). Przy okazji praca jest dość łatwym, ale kompleksowym przedstawieniem socjologii Bourdieu oraz, co ważne, pozostaje unikatowym wglądem w modus operandi teorii francuskiego socjologa. Krok po kroku ujawnia specyficzny sposób teoretyzowania, unaocznia analizę prawdziwie refleksyjna, wymuszającą ciagłe obiektywizowanie siebie jako podmiotu, który obiektywizować ma badaną rzeczywistość. Analiza rewolucji Maneta jest także, a może przede wszystkim, przewrotnym autoportretem samego Bourdieu. Przy wszystkich różnicach rewolucje, których dokonali - Manet w malarstwie i Bourdieu w socjologii - maja wiele punktów wspólnych. Pod pewnym względami ich trajektorie oraz habitusy także są podobne, zwłaszcza w wymiarze wewnętrznego rozdarcia (zob. Bourdieu 2004). Bourdieu, jak Manet, uczulony był na kwestię niezależności wobec tego, co zewnętrzne, autonomię wobec „władzy doczesnej”. Obaj stanowili przy tym inkarnację czegoś większego, sił całych uniwersów - pola sztuki i pola socjologii. Obaj wreszcie zmienili ,zasady widzenia", uświęcone hierarchie, czy to w sztuce, czy w naukach społecznych. Jak sugeruje więc w krótkim tekście dołączonym do książki Pascale Casanova, Bourdieu mógłby śmiało powiedzieć, trawestując ulubionego przez siebie Flauberta: „Manet to ja” (Bourdieu 2013: 741).

Bibliografia:

/// Bourdieu P. 1967. Postface, [w:] E. Panofsky, Architecture Gotbique et Pensée Scolastique, Minuit, Paris [w niniejszym tomie, s. 163-187].

/// Bourdieu P. 1984. Homo academicus, Édition de Minuit, Paris.

/// Bourdieu P. 1987. Linstitutionnalisation de l'anomie, „Les cahiers du Musée national d'art moderne", 19-20 juin, s. 6-19.

/// Bourdieu P. 1988. L'ontologie politique de Martin Heidegger, Minuit, Paris.

/// Bourdieu P. 2001. Reguly sұtuki. Geneza i struktura pola literackiego, tłum. A. Zawadzki, Universitas, Kraków.

/// Bourdieu P. 2004. Esquisse pour une auto-analyse, Liber, Raisonsd'Agir, Paris.

/// Bourdieu P. 2005. Dystynkecja. Społeczna krytyka władzy sadzenia, tłum. P. Biłos, Wydawnictwo Naukowe Scholar, Warszawa. 
/// Bourdieu P. 2006. Medytacje pascalianskie, tłum. K. Wakar, Oficyna Naukowa, Warszawa.

/// Bourdieu P. 2013. Manet. Une révolution symbolique. Cours au collège de France (1998-2000), Raisons d'agir - Seuil, Paris.

/// Bourdieu P. 2012. Sur l'État. Cours an Collège de France (1989-1992), Raisons d'agir - Seuil, Paris.

/// Weber M. 2002. Gospodarka i społeczeńtwo. Zarys socjologii rozumiejacej, tłum. D. Lachowska, Państwowy Instytut Wydawniczy, Warszawa.

/// Weber M. 2006. Socjologia religii. Drieła zebrane. Etyka gospodarcza religii swiatowych, tłum. T. Zatorski, G. Sowinski, D. Motak, Nomos, Kraków. 